\title{
An automatic collector to monitor insoluble atmospheric deposition: application for mineral dust deposition
}

\author{
B. Laurent ${ }^{1}$, R. Losno ${ }^{1, a}$, S. Chevaillier ${ }^{1}$, J. Vincent ${ }^{1}$, P. Roullet ${ }^{2}$, E. Bon Nguyen ${ }^{1}$, N. Ouboulmane ${ }^{1}$, S. Triquet ${ }^{1}$, \\ M. Fornier ${ }^{3}$, P. Raimbault ${ }^{3}$, and G. Bergametti ${ }^{1}$ \\ ${ }^{1}$ Laboratoire Interuniversitaire des Systèmes Atmosphériques (LISA), UMR7583 CNRS, \\ Université Paris Diderot, Université Paris-Est Créteil, Institut Pierre-Simon Laplace, France \\ ${ }^{2}$ Ingénierie, Conseil, Assistance technique, Recherche, Etude (ICARE Ingénierie), Paris, France \\ ${ }^{3}$ Mediterranean Institute of Oceanography (MIO), UMR7294 CNRS, UMR235 IRD, Université \\ Aix-Marseille, Université du Sud Toulon-Var, France \\ a present address: Institut de Physique du Globe de Paris (IPGP), UMR7154 CNRS, Sorbonne \\ Paris Cité, Université Paris Diderot, France
}

Correspondence to: B. Laurent (benoit.laurent @lisa.u-pec.fr)

Received: 23 December 2014 - Published in Atmos. Meas. Tech. Discuss.: 2 March 2015

Revised: 6 June 2015 - Accepted: 16 June 2015 - Published: 16 July 2015

\begin{abstract}
Deposition is one of the key terms of the mineral dust cycle. However, dust deposition remains poorly constrained in transport models simulating the atmospheric dust cycle. This is mainly due to the limited number of relevant deposition measurements. This paper aims to present an automatic collector (CARAGA), specially developed to sample the total (dry and wet) atmospheric deposition of insoluble dust in remote areas. The autonomy of the CARAGA can range from 25 days to almost 1 year depending on the programmed sampling frequency (from 1 day to 2 weeks respectively). This collector is used to sample atmospheric deposition of Saharan dust on the Frioul islands in the Gulf of Lions in the Western Mediterranean. To quantify the mineral dust mass in deposition samples, a weighing and ignition protocol is applied. Almost 2 years of continuous deposition measurements performed on a weekly sampling basis on Frioul Island are presented and discussed with air mass trajectories and satellite observations of dust. Insoluble mineral deposition measured on Frioul Island was $2.45 \mathrm{~g} \mathrm{~m}^{-2}$ for February to December 2011 and $3.16 \mathrm{~g} \mathrm{~m}^{-2}$ for January to October 2012. Nine major mineral deposition events, measured during periods with significant MODIS aerosol optical depths, were associated with air masses coming from the southern Mediterranean Basin and North Africa.
\end{abstract}

\section{Introduction}

Mineral dust particles emitted from the Sahara are a factor in excessive daily air particles concentrations of $\mathrm{PM}_{10}$ (particulate matter less than $10 \mu \mathrm{m}$ in diameter) observed in the Mediterranean Basin and southern Europe (Pey et al., 2013). In order to estimate these Saharan dust outbreaks over this region, chemistry-transport models (CTM) could simulate continuous and forecasted dust concentration fields. Simulations of mineral dust are validated by comparing the simulated dust load with numerous available data sets, for instance direct aerosol concentration measurements and aerosol optical depth (AOD) derived from ground-based and/or satellite observations. However, this remains insufficient to ensure the consistency of regional or global dust simulations, because, due to the lack of quantitative measurements, emission and deposition can be adjusted quite freely to allow models to match observed atmospheric dust concentrations. This means that at least one additional term, emission or deposition mass flux, has to be measured to correctly constrain the simulated dust mass concentration.

Large uncertainties remain, for instance, on how dry and wet dust deposition processes are modelled (Zhao et al., 2003; Textor et al., 2006; Jung and Shao, 2006; Bergametti and Forêt, 2014). Few experimental field measurements of dust deposition have been performed recently (Guieu et al., 
2010; López-Garcia et al., 2013; Heimburger et al., 2013; Osada et al., 2014). Accurate measurements of dust mass fluxes remain scarce whereas they should be conducted continuously and homogenously over regions impacted by mineral dust in order to constrain model dust simulations. One of the reasons why such a small number of field studies has been performed is the heavy workload that both sampling and measurement of dust deposition represent over long periods of time.

This paper presents a new device designed to perform continuous dust deposition measurements over long periods and a weighing and ignition protocol to determine the total insoluble mineral dust mass deposited. This automatic collector, named CARAGA (Collecteur Automatique de Retombées Atmosphériques insolubles à Grande Autonomie), has been specially developed to sample total insoluble atmospheric particles deposition in remote areas and to insure robust automatic sampling with a large autonomy and a minimum need of man power. Since mid-2010, a collector sampling total (dry and wet) deposition has be installed on Frioul Island $\left(43.27^{\circ} \mathrm{N} ; 5.29^{\circ} \mathrm{E}\right)$, which is located in the Gulf of Lions in the north-western Mediterranean Sea, where Saharan dust outbreaks can be observed (see for example Ridame et al., 1999). In the following sections, the in situ deposition sampling strategy is presented as well as the lab protocol established to quantify mineral dust deposition. Almost 2 years of mineral deposition measurements on Frioul Island are discussed and open up the possibility to develop a CARAGA sampling network of total insoluble deposition in remote areas.

\section{Previous studies of dust deposition sampling}

Dry deposition mainly depends on sedimentation, interception, impaction and Brownian diffusion processes (Slinn and Slinn, 1980; Wesely, 1989; Venkatram and Pleim, 1999). Wet deposition processes correspond to the capture of particles by droplets either inside or below the clouds (Dana and Hales, 1976; Slinn, 1984; Garcia Nieto et al., 1994). These deposition processes of atmospheric particles are supposed to be well understood. However, most of the theoretical understanding and parameterizations of deposition were based on studies and measurements performed under controlled conditions, for instance in wind tunnels (Chamberlain, 1967; Goossens, 2008) or towers and laboratories (Wang and Pruppacher, 1977; Leong et al., 1982; Barlow and Latham, 1983; Pranesha and Kamra, 1996).

In situ dust deposition measurements of atmospheric particles are technically difficult and have to be adapted depending on the aim of the study: dry, wet or total deposition; soluble, insoluble or bulk deposition; short- or long-term sampling, etc. Quantitative estimates of dust deposition remain challenging (see for example Wiggs et al., 2002; Goossens and Rajot, 2008). Various techniques have been proposed to directly measure or to estimate (from atmospheric concentra- tions) dry deposition of dust on surfaces (Seinfeld and Pandis, 1998; Etyemezian et al., 2003; Goossens, 2005; Sow et al., 2006). Experimental studies usually show a wide range in dry deposition values, depending on the sampling device (Goossens and Rajot, 2008). Even if wet deposition measurements are easier to perform, correctly sampling the first millimetres of a precipitation event is crucial to precisely measure wet deposition (Claassen and Halm, 1995). In the framework of this study, the sampling of total (dry and wet) Saharan dust deposition is investigated.

Up to now, Saharan dust deposition sampling has required frequent human intervention to be carried out. Most of the time, deposition collectors consist of simple passive collecting systems: funnel capped bottles (Markaki et al., 2010; Prospero et al., 2010), polyethylene bottles (Bonnet and Guieu, 2006; Markaki et al., 2010), bags (Galy-Lacaux et al., 2009), buckets (Prospero et al., 2010) or surfaces covered with glass marbles (Kouvarakis et al., 2001; Sow et al., 2006). Similar collectors have been used to sample mineral dust in other regions, for example in Asia by Osada et al. (2014) or the Kerguelen islands in the Southern Ocean (Heimburger et al., 2013). None of these collecting systems allows the automatical sampling of dust deposition with sufficient autonomy in order to limit human intervention after each sampling.

In the Mediterranean Basin, Saharan dust deposition was sampled in Capo Cavallo (NW Corsica) using a CRAPAL sampler (Bergametti, 1987; Remoudaki et al., 1991), which is a hemispheric plexiglass collection device $\left(0.1 \mathrm{~m}^{2}\right)$ with a $10 \mathrm{~cm}$ high neck covered by a $1 \mathrm{~mm}$ nylon mesh (Lambert and Nezami, 1965). Its base is connected to an acidcleaned polyethylene bucket in which the atmospheric deposition is collected during precipitation and by manual acid flushing at the end of a 1-week sampling period. Loÿe-Pilot and Martin (1996) also collected Saharan dust deposition in Corsica during an 11-year period (1984-1994) using a bulk plastic collector (Standard Rain Gauge) which has a $400 \mathrm{~cm}^{2}$ aperture. Deposition measurements were also performed on the two sides of the Ligurian Sea at the Cap Ferrat site in 2004 and 2006 (Bonnet and Guieu, 2006; Pulido-Villena et al., 2008) and in Corsica in 2003 and 2005 (Ternon et al., 2010) using the same bulk plastic collector or a funnel and a polyethylene bottle. The most comprehensive field study to assess the magnitude and the composition of atmospheric deposition in the Mediterranean Basin was the ADIOS program, during which atmospheric deposition was collected at 10 sampling sites (Guieu et al., 2010; Markaki et al., 2010). The mass of deposited Saharan dust was estimated from the measured Al amount. The sampling device collected bulk samples (dry and wet deposition) using a 1 gallon Nalgene high-density polyethylene bottle with a polyethylene funnel $\left(0.011 \mathrm{~m}^{2}\right)$ attached at its top. The sampling duration was 1 month for each sample and it required human intervention.

Total dust deposition was also collected in the Sahelian region using a CAPYR sampler (Orange et al., 1990; Her- 
rmann, 1996; Rajot, 2001). The CAPYR is a $40 \mathrm{~cm}$ high funnel-shaped sampler with a $0.25 \mathrm{~m}^{2}$ horizontal inlet opening. It was used to collect total dust deposition in Niger from 1996 to 1998 (Rajot, 2001). In Niger, a Frisbee sampler, which consists of a circular stainless steel collecting bowl $\left(0.07 \mathrm{~m}^{2}\right.$ and $3.6 \mathrm{~cm}$ deep) surrounded by an aerodynamically shaped aluminum deflector ring (Wiggs et al., 2002), was also used to collect total dust deposition (Sow et al., 2006). This device requires manual rinsing to collect total deposition.

To collect dry and wet Saharan dust deposition separately, ARS MTX or Aerochem Metrics model 301 samplers were used on the Eastern and Western Mediterranean coasts (Ozsoy, 2003; Morales-Baquero et al., 2013) and on Canary Islands (López-Garcia et al., 2013). To perform successive samples, the collect systems have to be manually replaced. Wet deposition was also collected with wet-only collectors in the Eastern Mediterranean (Theodosi et al., 2010), in Niger (Galy-Lacaux et al., 2009) and Florida (Prospero et al., 2010). The conservation of the deposition soluble fraction over time strongly limits the autonomy of the sampling device.

These various approaches (and associated samplers) have technical drawbacks on the field that have limited their development in terms of sampling network expansion or duration. This is especially due to a short autonomy, as human intervention is required to replace the collect system after each sampling period. Therefore, a robust automatic system is necessary to achieve low costs in the long term and a wide area network survey system.

\section{New sampler and method to study mineral dust deposition}

\subsection{The CARAGA collector}

The existing deposition samplers are not automatized and/or not autonomous over long periods. This constitutes a strong limitation to performing continuous in situ measurements of atmospheric deposition in the long term and in remote areas. The ICARE Ingénierie Company and the Laboratoire Interuniversitaire des Systèmes Atmosphériques (LISA) developed a collector to automatically sample total insoluble deposition on filters over long periods without any human intervention: the Collecteur Automatique de Retombées Atmosphériques insolubles à Grande Autonomie. It is used to estimate the mass of deposited dust during a given time period in order to better constrain CTM dust simulations. By focusing on the total insoluble mass of deposited dust, the sampling device can be significantly simplified, which limits the issues associated to the change and storage of the samples. In order to estimate the deposited mass, collecting only the insoluble part of the dust deposition is justified by the very large fraction (over $80 \%$ ) of insoluble matter in the Sa- haran dust deposition in the Mediterranean Basin (see for example Losno, 1989; Guerzoni et al., 1993; Avila et al., 2007).

The CARAGA is composed of separate modules to facilitate its transport and in situ implementation (see Supplement). An open circle funnel $\left(0.2 \mathrm{~m}^{2}\right)$ forms the top part of the CARAGA collector (Fig. 1). The collecting surface ensures sufficient sampling during non-intense deposition events and avoids the saturation of the collecting filter in case of intense deposition events. Local soil dust contamination can be a problem for measurements, especially during periods of high wind speed. In order to minimize this contamination, the funnel is fixed on a steel structure and an adjustable tripod 2.5 to $3 \mathrm{~m}$ above the ground (Fig. 1). A PTFE strainer is installed in the funnel to limit the impact of large insects or vegetal debris (larger than $2 \mathrm{~mm}$ ) on the sampling. In order to diminish the risk of bird standing, the top of the funnel is made thin and sharp. If the temperature drops down to $2{ }^{\circ} \mathrm{C}$, the funnel walls are heated with heating tapes. The funnel is connected by a short tube to a 25 -hole carousel which carries filters mounted in separate filter holders (Figs. 1 and S1 in the Supplement).

Two hours and $1 \mathrm{~h}$ before the end of each sampling period, a device vibrates the funnel walls and $100 \mathrm{~mL}$ of pure water, or a blend of $20 \%$ ethanol in pure water in case of frost, is sprayed to drive down the atmospheric deposited particles and collect them on a $47 \mathrm{~mm}$ diameter membrane filter. This sample procedure is identically reproduced for each sample and does not require any operator intervention. Rain events are directly collected by the funnel. The filtration is performed by gravity and only the insoluble matter is collected on the filter; the remaining water is eliminated. An electronic system can be adapted to control the water level in the filter holder and periodically closes a pinch valve installed on the tube at the bottom of the funnel if this level is too high. This avoids overflow of the filter holder and the loss of a part of the wet deposition in case of heavy rain.

Twenty-five lab-prepared filters are installed in filter holders on the motorized carousel (Fig. S1). A new filter is automatically set in the sampling position for each new sampling period. The sampling duration can be programmed and the autonomy of the instrument ranges from 25 days for daily sampling to almost 1 year for sampling on a 2 -week basis. For post-control, an electronic recorder stores the date at which the rotating unit has worked. A solar panel $(20 \mathrm{~W})$ connected to a battery $(12 \mathrm{~V}, 7 \mathrm{Ah})$ supplies the power.

The CARAGA system is best suited for the collection of the non-soluble fraction of dust, but it could also be used for evaluating other inorganic or organic particles after adapting the sampling and lab protocols.

\subsection{Filter choice}

The mass of mineral dust is considered to be dominated by large particles (Whitby and Cantrell, 1976) contributing to PM concentrations in the Mediterranean area (Pey et 


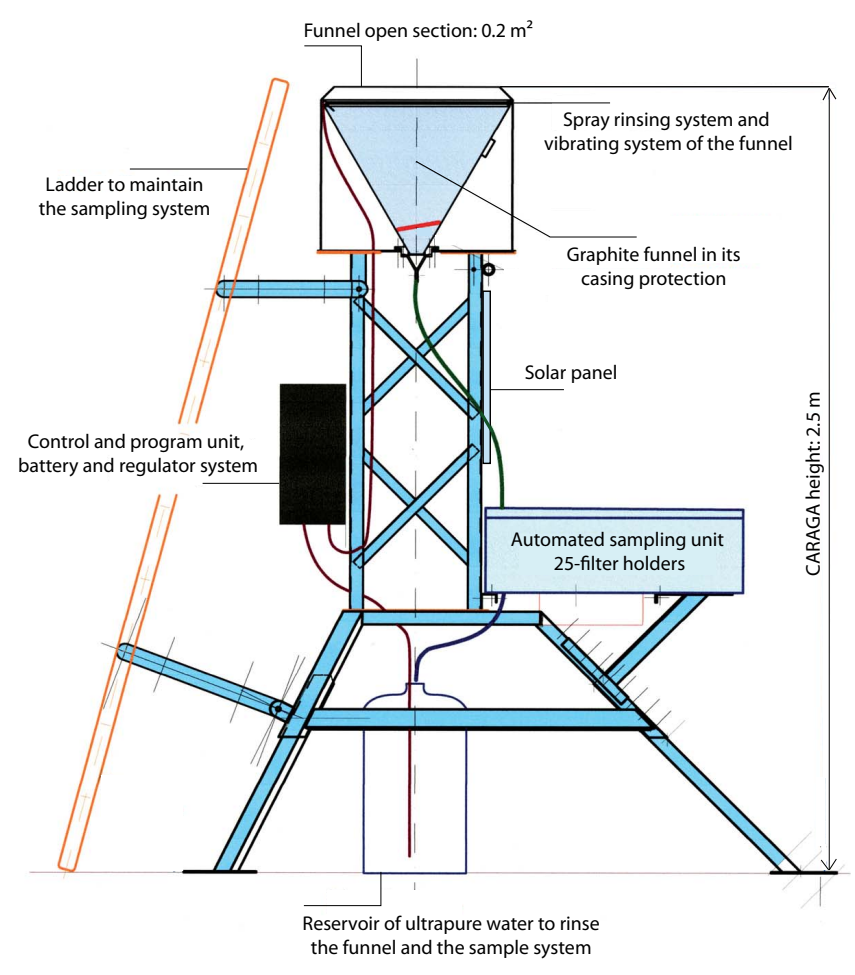

Figure 1. Schema of the CARAGA collector. Height of the collector can be extended to $1 \mathrm{~m}$ more by adding a second pillar spacer.

al., 2013). Sciare et al. (2005) presented average concentrations for PM and chemical species at two sampling sites in Eastern Mediterranean Sea during the MINOS campaign in August 2001. They distinguished fine $(<1.2 \mu \mathrm{m})$ and coarse (> $1.2 \mu \mathrm{m}$ ) particles, and showed that 90 to $95 \%$ of dust concentrations are in the coarse mode, while 84 to $87 \%$ of the black carbon and $82 \%$ of the organic carbon are in the fine mode.

In order to choose the optimal filter for collecting dust deposition, several tests were performed. Since filtration is gravity driven only, the water flow through different filter membranes composed of polycarbonate, quartz or cellulose were tested: (i) AOX Nuclepore ${ }^{\odot}$ polycarbonate filter ( $\varnothing 47 \mathrm{~mm}, 0.4 \mu \mathrm{m}$ porosity), (ii) nylon filter ( $\varnothing 47 \mathrm{~mm}$, $0.45 \mu \mathrm{m}$ porosity), (iii) cellulose nitrate filter $(\varnothing 0.47 \mathrm{~mm}$, $0.45 \mu \mathrm{m}$ porosity), (iv) AA Millipore ${ }^{\odot}$ cellulose ester filter ( $\varnothing 47 \mathrm{~mm}, 0.8 \mu \mathrm{m}$ porosity) and (v) QMA Whatman ${ }^{\odot}$ quartz fiber filter ( $\varnothing 47 \mathrm{~mm}, 2.2 \mu \mathrm{m}$ porosity). The test consisted of determining the time required to drain $100 \mathrm{~mL}$ of pure water through the filter. The AA Millipore cellulose ester filter with a $0.8 \mu \mathrm{m}$ porosity is the only filter type for which a reasonable flow speed is obtained, about $20 \mathrm{~mL} \mathrm{~min}^{-1}$ (Table 1). Moreover, Sheldon (1972) indicates that Millipore ${ }^{\odot}$ cellulose ester filters, with a porosity ranging from 0.45 to $8 \mu \mathrm{m}$, have high percentages of retention of particles of $1 \mu \mathrm{m}$ ranging from 80 to $100 \%$.
To test a possible mass loss by dissolution of the filter in water, six cellulose ester blank filters were weighed before and after filtration of $250 \mathrm{~mL}$ of pure water. In this study, the weighings were conducted using a Mettler ${ }^{\odot}$ AE240 electronic microbalance (sensitivity $10^{-4} \mathrm{~g}$ ). For the weighing of the filters, an aluminium crucible was used to prevent electrostatic issues. Each sample was weighed until two equal successive displayed values were obtained. After filtration, different treatments were tested $\left(1 \mathrm{~h}\right.$ in an oven at $40^{\circ} \mathrm{C}, 3 \mathrm{~h}$ in an oven at $40^{\circ} \mathrm{C}, 17 \mathrm{~h}$ at ambient $T^{\circ} \mathrm{C}$ and $23 \mathrm{~h}$ at ambient $T^{\circ} \mathrm{C}$ ). The results show a mass variation of $\pm 3 \times 10^{-4} \mathrm{~g}$.

\subsection{Weighing and ignition protocol}

To correctly quantify the deposited mass of mineral dust, an adapted protocol has to be defined that accounts for the complex blending of particles constituting the atmospheric particulate deposition.

The weighing of the first in situ filters revealed specific constraints. The particles can have a diameter up to $10 \mu \mathrm{m}$ and therefore may not strongly adhere to the filter. Loss of particles during filter handling is possible, especially for filters highly loaded with particles. Furthermore, the aim of the present study being to characterize the deposition mass of Saharan dust, particles having a biogenic origin (e.g. organic aerosols) or being derived from emissions of pollutants or biomass burning can affect the estimate.

In order to eliminate the organic fraction of a sample, ignition protocols with temperatures ranging from 375 to $850^{\circ} \mathrm{C}$ were used in previous studies (Ball, 1964; Hoenig and Thomas, 2002; Sun et al., 2009). This kind of protocol reduces the filter handling and eliminates the deposited particles with medium to high volatility, as is the case for most of organic aerosols.

In the present study, we followed a weighing protocol after ignition of the samples. First, blank filters were placed in ceramic crucibles with their lids ajar in an ashing furnace (Naberthem ${ }^{\odot}$ LT15/11). Various programs of temperature increase to reach 350,550 and $950^{\circ} \mathrm{C}$ were tested. To prevent a flame that can lead to loss of material during calcination, the tests point out the necessity to control the temperature increase between 200 and $350^{\circ} \mathrm{C}$ at a rate of $1^{\circ} \mathrm{C} \mathrm{min}^{-1}$. The residual ash mass of the filters was weighed after different cycles of ignition at 350,550 and $950{ }^{\circ} \mathrm{C}$. The calcination of AA Millipore ${ }^{\odot}$ cellulose ester blank filters showed their complete destruction between 350 and $550^{\circ} \mathrm{C}$. Two triplicates of this test were performed and consecutive weighings were carried out to control the balance stability. There is no detectable residue of the filter by weighing after ignition.

Comparative tests between direct weighing and weighing after ignition at 350,550 and $950^{\circ} \mathrm{C}$ were performed using (i) proxies of mineral dust prepared on filters by crushing a desert erodible soil collected in Douz (Tunisia) and a loess soil collected on Sal Island (Cape Verde), as well as (ii) the first filters collected at the Frioul site. Each filter is first 
Table 1. Flow times to drain $100 \mathrm{~mL}$ water using various filter membranes.

\begin{tabular}{lrrrrr}
\hline Filter & AOX & Nylon & Cellulose nitrate \\
$0.4 \mu \mathrm{m}$ & $0.45 \mu \mathrm{m}$ & $0.45 \mu \mathrm{m}$ & $\begin{array}{r}\text { Cellulose esters } \\
0.8 \mu \mathrm{m}\end{array}$ & $\begin{array}{r}\text { Quartz } \\
2.2 \mu \mathrm{m}\end{array}$ \\
\hline Flow time (min) & 67 & 55 & 12 & 5 & 15 \\
\hline
\end{tabular}

Table 2. Masses of crushed soil fraction (Douz in Tunisia and Cape Verde in Senegal) deposited on cellulose ester filters and measured before and after ignition at 350,550 and $950^{\circ} \mathrm{C}$.

\begin{tabular}{lrrrrr}
\hline Sample & Deposit $(\mathrm{g})$ & $\begin{array}{r}\text { Filter }+ \text { deposit }(\mathrm{g}) \\
\text { no ignition }\end{array}$ & $\begin{array}{r}\text { Filter }+ \text { deposit }(\mathrm{g}) \\
350{ }^{\circ} \mathrm{C} \text { ignition }\end{array}$ & $\begin{array}{r}\text { Filter }+ \text { deposit }(\mathrm{g}) \\
550^{\circ} \mathrm{C} \text { ignition }\end{array}$ & $\begin{array}{r}\text { Filter }+ \text { deposit }(\mathrm{g}) \\
950^{\circ} \mathrm{C} \text { ignition }\end{array}$ \\
\hline Douz 1 & 0.126 & 0.215 & 0.131 & 0.122 & 0.113 \\
Douz 2 & 0.134 & 0.217 & 0.137 & 0.128 & 0.119 \\
Douz 3 & 0.257 & 0.337 & 0.260 & 0.251 & 0.240 \\
Cape Verde 1 & 0.012 & 0.095 & 0.018 & 0.011 & 0.012 \\
Cape Verde 2 & 0.012 & 0.098 & 0.015 & 0.011 & 0.012 \\
Cape Verde 3 & 0.015 & 0.100 & 0.020 & 0.013 & 0.015 \\
\hline
\end{tabular}

weighed alone, before and after sampling (after sampling filters are dried $2 \mathrm{~h}$ up to $40^{\circ} \mathrm{C}$ to limit remaining humidity) and then in its crucible with lid before and after ignition.

Three filters of the Douz crushed soil $(0.126,0.133$ and $0.257 \mathrm{~g}$ ) and three filters of the Cape Verde crushed loess $(0.012,0.012$ and $0.015 \mathrm{~g})$ were prepared after a passive filtration of the soil samples suspended in a water solution. The results of direct weighing as well as weighing of the samples after calcination at 350,550 and $950{ }^{\circ} \mathrm{C}$ are presented in Table 2. At $350^{\circ} \mathrm{C}$, filters residues are still present and contribute to the mass of the sample. This is no longer the case at 550 and $950{ }^{\circ} \mathrm{C}$. The masses of the samples after ignition at $550{ }^{\circ} \mathrm{C}$ are lower than the initial masses (Douz 1: $-3.2 \%$, Douz 2: $-4.5 \%$, Douz 3: $-2.3 \%$; Cape Verde 1: $-8.3 \%$, Cape Verde $2:-8.3 \%$, Cape Verde $3:-13.3 \%$ ). This tendency is reinforced at $950^{\circ} \mathrm{C}$ (Table 2). The same tests were conducted for samples collected on Frioul Island (Table 3). For the three filters with deposition masses varying over an order of magnitude $(\mathrm{F} 7=0.011 \mathrm{~g}, \mathrm{~F} 8=0.091 \mathrm{~g}$ and $\mathrm{F} 9=0.145 \mathrm{~g}$ ), a greater loss on ignition is observed at $550{ }^{\circ} \mathrm{C}(18.2,9.9$ and $9.6 \%$ respectively) compared to the samples from Douz and Cape Verde. For filters without high load of particles, the loss is the same order of magnitude as the uncertainty on the protocol. The six other filters showed no detectable deposition and are used to test the repeatability and the uncertainty of the method used to determine the mass of mineral deposit after ignition.

These tests point out that a temperature of $550{ }^{\circ} \mathrm{C}$ ensures the loss on ignition of the filter and of the organic matter which is destroyed below $450^{\circ} \mathrm{C}$ (Hoenig and Thomas, 2002). Moreover, Sun et al. (2009) recorded only a small mass loss (lower than $0.2 \%$ ) for quartz, feldspar, calcite and hematite during ignition at $550{ }^{\circ} \mathrm{C}$. Mass losses between 1 and $2.5 \%$ for smectite, chlorite, illite and goethite and up to $18 \%$ for kaolinite were observed (Sun et al., 2009). These au- thors showed that the structural water loss for 17 soil samples ranges from 0.56 to $2.45 \%$ at $550^{\circ} \mathrm{C}$. This is consistent with the mass loss results obtained for the Douz soil which contains a significant proportion of quartz and calcite (Lafon et al., 2014). The larger mass loss observed for the Cape Verde soil can be partly due to its composition of quartz, potassic feldspars and an assemblage of illite-kaolinite-chlorite (Rognon et al., 1996; Desboeufs et al., 1999). The larger loss on ignition observed for the atmospheric deposition suggests a higher fraction of volatile compounds in the Frioul samples than in the tested soils.

A maximum temperature of $550^{\circ} \mathrm{C}$ was chosen for the ignition protocol applied to the collected samples. To ensure a slow combustion of the membrane filter and the destruction of the organics, heating was carried out in four steps (Table 4): the first segment from 20 to $200^{\circ} \mathrm{C}$ in $40 \mathrm{~min}$, the second segment from 200 to $350^{\circ} \mathrm{C}$ in $150 \mathrm{~min}$, the third segment from 350 to $550^{\circ} \mathrm{C}$ in $45 \mathrm{~min}$ and the fourth segment stabilized at $550^{\circ} \mathrm{C}$ during $120 \mathrm{~min}$. Afterwards, the crucibles were cooled down inside the furnace at ambient temperature.

Direct weighing of filters and their weighing after ignition lead to the same level of accuracy (mass uncertainty less than $10^{-3} \mathrm{~g}$ ). However, direct weighing of filters is more restrictive for samples containing large amounts of coarse particles and organic residues. Weighing after ignition limits filter manipulations and therefore the possible loss of a part of the sample. Moreover, this protocol focuses on the mineral fraction of the deposition, most of the organic particles being volatilized or oxidized when the final temperature reaches $550^{\circ} \mathrm{C}$.

Other insoluble aerosols from anthropogenic activities and biomass burning are also present in the Mediterranean atmosphere and can affect the deposition measurements. Field studies performed in the Eastern Mediterranean Basin 
Table 3. Masses collected on cellulose ester filters on Frioul Island before and after ignition at 350,550 and $950{ }^{\circ} \mathrm{C}$.

\begin{tabular}{lrrrrr}
\hline Sample & Deposit $(\mathrm{g})$ & $\begin{array}{r}\text { Filter }+ \text { deposit }(\mathrm{g}) \\
\text { no ignition }\end{array}$ & $\begin{array}{r}\text { Filter }+ \text { deposit }(\mathrm{g}) \\
350^{\circ} \mathrm{C} \text { ignition }\end{array}$ & $\begin{array}{r}\text { Filter }+ \text { deposit }(\mathrm{g}) \\
550^{\circ} \mathrm{C} \text { ignition }\end{array}$ & $\begin{array}{r}\text { Filter }+ \text { deposit }(\mathrm{g}) \\
950^{\circ} \mathrm{C} \text { ignition }\end{array}$ \\
\hline Filter F7 & 0.011 & 0.089 & 0.017 & 0.009 & 0.009 \\
Filter F8 & 0.091 & 0.165 & 0.090 & 0.082 & 0.068 \\
Filter F9 & 0.145 & 0.221 & 0.139 & 0.131 & 0.106 \\
Filter F10 & $0.000^{*}$ & 0.076 & 0.003 & 0.000 & 0.001 \\
Filter F11 & $0.000^{*}$ & 0.075 & 0.007 & 0.000 & 0.001 \\
Filter F12 & $0.000^{*}$ & 0.077 & 0.002 & 0.000 & 0.001 \\
Filter F13 & $0.000^{*}$ & 0.077 & 0.001 & 0.000 & 0.000 \\
Filter F14 & $0.000^{*}$ & 0.078 & 0.003 & 0.001 & 0.001 \\
Filter F15 & $0.000^{*}$ & 0.078 & 0.003 & 0.001 & 0.000 \\
\hline
\end{tabular}

* In situ control filter without any deposit.

Table 4. Ignition gradient protocol.

\begin{tabular}{lrrrr}
\hline$T^{\circ}$ range & $0-200{ }^{\circ} \mathrm{C}$ & $200-350{ }^{\circ} \mathrm{C}$ & $350-550{ }^{\circ} \mathrm{C}$ & $550{ }^{\circ} \mathrm{C}$ \\
Time & $40 \mathrm{~min}$ & $150 \mathrm{~min}$ & $45 \mathrm{~min}$ & $120 \mathrm{~min}$ \\
$T^{\circ}$ gradient & $5^{\circ} \mathrm{C} \mathrm{min}^{-1}$ & $1^{\circ} \mathrm{C} \mathrm{min}^{-1}$ & $4.5^{\circ} \mathrm{C} \mathrm{min}^{-1}$ & - \\
\hline
\end{tabular}

pointed out that these particles are mainly in the fine submicron aerosol fraction (Lelieveld et al., 2002) and that their mean mass concentrations are 1 order of magnitude lower than natural dust ones (Sciare et al., 2005). From atmospheric measurements performed in Corsica for elements indicating the major aerosol sources (natural and anthropogenic), Bergametti et al. (1989) concluded that strong daily variations of concentrations were mainly due to Saharan dusts inputs (for the crustal elements) and to the removal of aerosols by precipitation events. These results point out that anthropogenic aerosols and biomass burning present in the Mediterranean atmosphere could constitute a background deposition flux. However, mineral deposition sampled on filters during Saharan dust outbreaks is mainly due to Saharan dust.

\section{Deposition measurements on Frioul Island}

A CARAGA collector was installed mid-2010 on Frioul Island $\left(43.27^{\circ} \mathrm{N} ; 5.29^{\circ} \mathrm{E}\right)$, situated in the Gulf of Lions off Marseille. One of the main constraints with Saharan dust sampling is that their transport from source regions towards the Mediterranean Sea and Europe is sporadic. The sampling time needs to be short enough to catch dust transport events individually but long enough to provide sufficient autonomy to the CARAGA. Dust fallout events are brief and usually less than 3 days long (Loÿe-Pilot and Martin, 1996). A sampling duration of 1 week is adapted for collecting mineral particles corresponding to dust transport and deposition over the Mediterranean Basin. This sampling frequency also guaranties a large autonomy of the collector (up to 25 weeks depending on the desired number of in situ blank filters).
In order to collect the deposited particles on the filter, the funnel vibrates and is rinsed with $100 \mathrm{~mL}$ of pure water twice ( 2 and $1 \mathrm{~h}$ before the filter change). To bring back the samples to the laboratory, a suitcase designed to keep 25 filter holders with their lids in an upright position is used. Figure S2 visualizes the filters set collected on Frioul Island between July and December 2011. The different colours of the filters illustrate the variation in mass and the nature of the deposition from one week to another. Insects, vegetal debris, pollens or other organic matters collected on the filters are manually removed only if this manipulation does not affect the sample. If the removal of these elements could damage the sample, we leave them on the filter and the ignition of the samples at $550^{\circ} \mathrm{C}$ eliminates these organic matters. The mineral mass fluxes of the weekly total (dry and wet) insoluble deposition for samples collected from February 2011 to October 2012 are reported in Fig. 2. The precipitation rates measured on Frioul Island are also presented in Fig. 2 in order to point out the potential wet deposition occurring during precipitation events.

The insoluble mineral deposition measured on Frioul Island is $2.45 \mathrm{~g} \mathrm{~m}^{-2}$ for February to December 2011 and $3.16 \mathrm{~g} \mathrm{~m}^{-2}$ for January to October 2012, which corresponds to low deposition amounts without very strong dust events in this area of the Mediterranean Basin. Loÿe-Pilot and Martin (1996) measured an average annual dust deposition flux of $12.5 \mathrm{~g} \mathrm{~m}^{-2}$ in Corsica for an 11-year period between 1984 and 1994, with annual deposition fluxes varying from 4.0 to $26.2 \mathrm{~g} \mathrm{~m}^{-2} \mathrm{yr}^{-1}$. They mentioned that high magnitude events drive the variability of dust fallout at an annual and interannual scale. They also showed that most of Saharan events in Corsica are associated to wet deposition. Ternon 


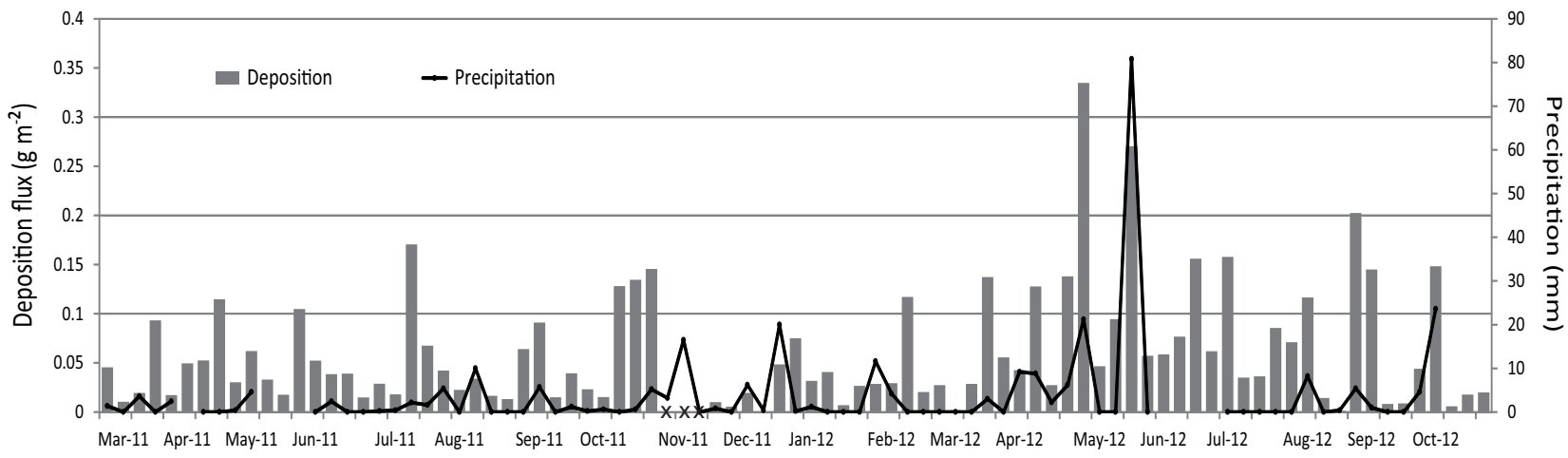

Figure 2. Weekly total insoluble deposition $\left(\mathrm{g} \mathrm{m}^{-2}\right.$ with an uncertainty of $\pm 5 \times 10^{-3} \mathrm{~g}$ ) and weekly precipitation rate (mm) on Frioul Island from February 2011 to October 2012. The filter was not automatically changed between the end of October and mid-November 2011. The accumulated deposited flux for this 3-week period is $0.26 \mathrm{~g} \mathrm{~m}^{-2}$ and is not reported on the figure (black crosses).

et al. (2010) found an average annual deposition value of $11.4 \mathrm{~g} \mathrm{~m}^{-2}$ at Cap Ferrat and Corsican sites between 2003 and 2006. Their measurements showed a high range of frequency and intensity of Saharan dust deposition events: very low $\left(510^{-2} \mathrm{~g} \mathrm{~m}^{-2}\right)$ dust flux events occurred relatively often ( 27 events in 4 years), and there was only one extreme event of $22 \mathrm{~g} \mathrm{~m}^{-2}$ representing almost $90 \%$ of the deposition in 2004.

The weekly total insoluble deposition fluxes of mineral dust at the Frioul site also exhibit a large variability ranging over 2 orders of magnitude, from no noticeable deposition (in the range of the uncertainty) to $3.3 \times 10^{-1} \mathrm{~g} \mathrm{~m}^{-2}$ (Fig. 2). About $60 \%$ of the measured deposition fluxes at the Frioul site are lower than $5 \times 10^{-2} \mathrm{~g} \mathrm{~m}^{-2}$. This indicates that, most of the time, mineral deposition on Frioul Island can be attributed to low deposition due to atmospheric particles background. Nine major events with mineral deposition fluxes ranging from $1.5 \times 10^{-1}$ to $3.3 \times 10^{-1} \mathrm{~g} \mathrm{~m}^{-2}$ have been recorded on this site between (a) 07 and 14 July 2011, (b) 20 and 27 October 2011, (c) 26 April and 03 May 2012, (d) 17 and 24 May 2012, (e) 14 and 21 June 2012, (f) 28 June and 5 July 2012, (g) 23 and 30 August 2012, (h) 30 August and 06 September 2012 and (i) 27 September and 04 October 2012. In 2011 and 2012, major deposition events occurred more frequently in late spring and summer. Precipitations ranging from 1.0 to $80.8 \mathrm{~mm}$ were measured on Frioul Island for seven of these event periods ( $a, b, c, d, g$, $\mathrm{h}$ and $\mathrm{i}$ ), precipitation data being totally or partly missing for two event periods ( $e$ and $f$ respectively).

The monthly average insoluble deposition fluxes measured at the Frioul site from February 2011 to October 2012 are presented in Fig. 3. The range of these fluxes (from 100 to $470 \mathrm{mg} \mathrm{m}^{-2}$ ) is comparable to measurements previously performed in Cap Ferrat (Bonnet and Guieu, 2006; PulidoVillena et al., 2008) in 2004 and 2006 and Corsica in 2003 and 2005 on both sides of the Ligurian Sea (see more details in Ternon et al., 2010). The measurements performed in Cor-
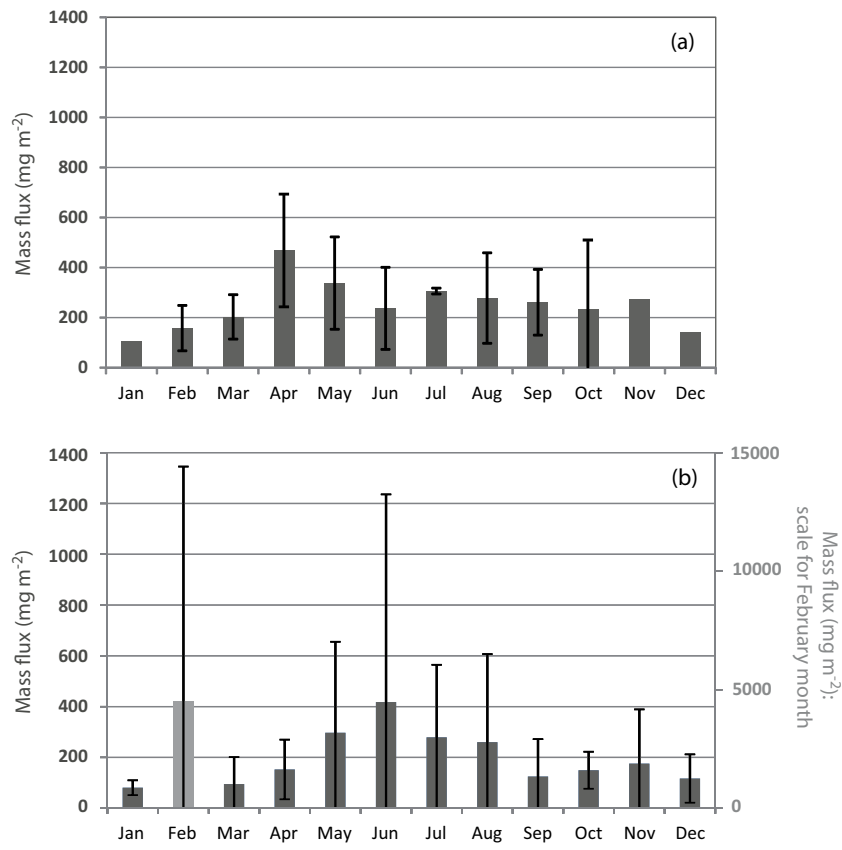

Figure 3. Monthly average insoluble atmospheric deposition in $\mathrm{mg} \mathrm{m}^{-2}$ (a) measured at the Frioul site from February 2011 to October 2012 in the framework of this study and (b) measured in Cap Ferrat and Corsica for 2003-2006 as presented in Ternon et al. (2010) (the scale for February, on the right $y$ axis of panel (b), is different in order to take into account an extreme Saharan event occurring in February 2004; Ternon et al., 2010). The standard deviations of the mean monthly values are reported (bars) except for January, November, and December because no measurements were performed in 2011 or 2012.

sica between 1984 and 1994 by Loÿe-Pilot and Martin (1996) show higher monthly deposition amounts ranging from about 200 to $2500 \mathrm{mg} \mathrm{m}^{-2}$. The monthly deposition measurements on Frioul Island show a maximum in early spring (AprilMay) in agreement with the measurements of Loÿe-Pilot and 


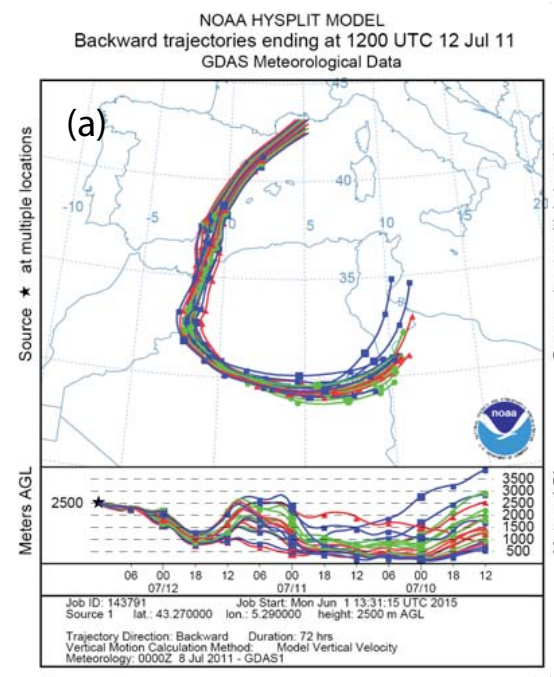

NOAA HYSPLIT MODEL Backward trajectories ending at 1800 UTC 20 May 12

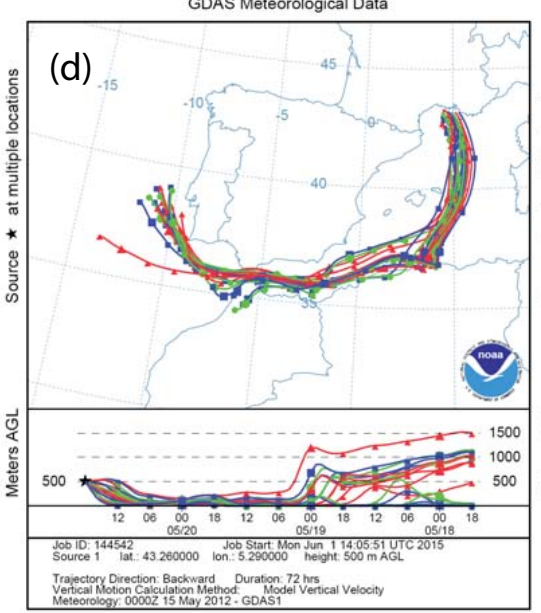

NOAA HYSPLIT MODEL

Backward trajectories ending at 1200 UTC 25 Aug 12 GDAS Meteorological Data

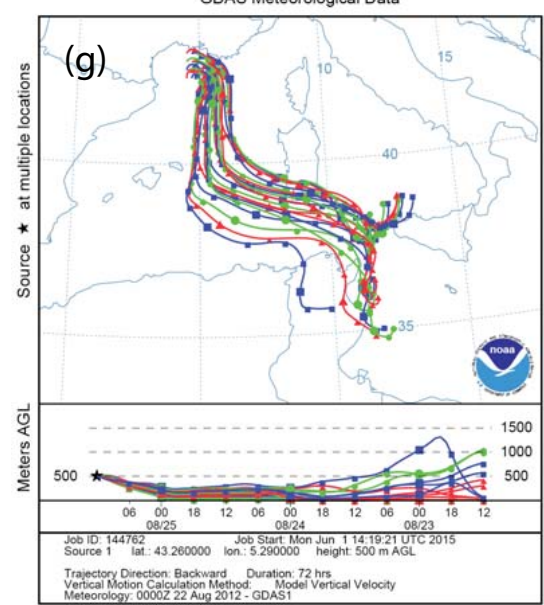

NOAA HYSPLIT MODEL

Backward trajectories ending at 0000 UTC 25 Oct 11 GDAS Meteorological Data

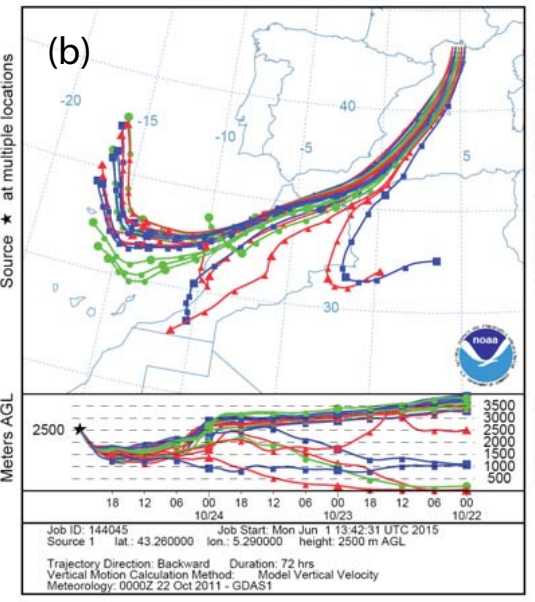

NOAA HYSPLIT MODEL

Backward trajectories ending at 1200 UTC 20 Jun 12 GDAS Meteorological Data

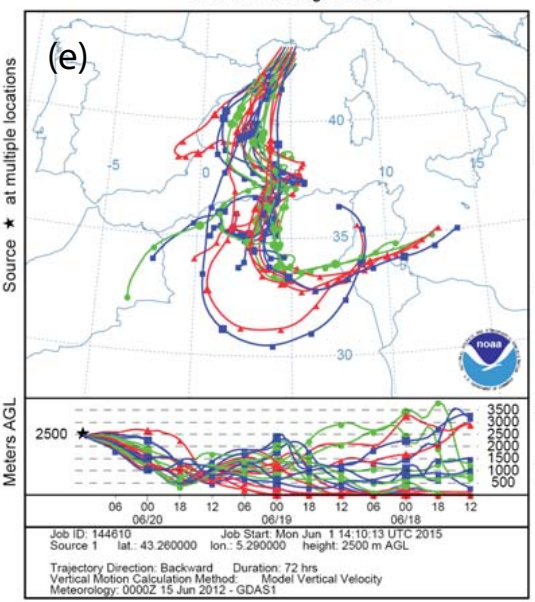

NOAA HYSPLIT MODEL GDAS Meteorological Data

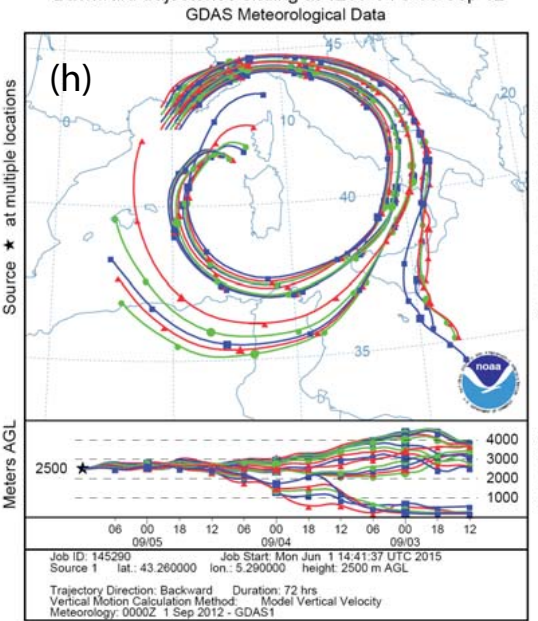

NOAA HYSPLIT MODEL

Backward trajectories ending at 1200 UTC 30 Apr 12 GDAS Meteorological Dat

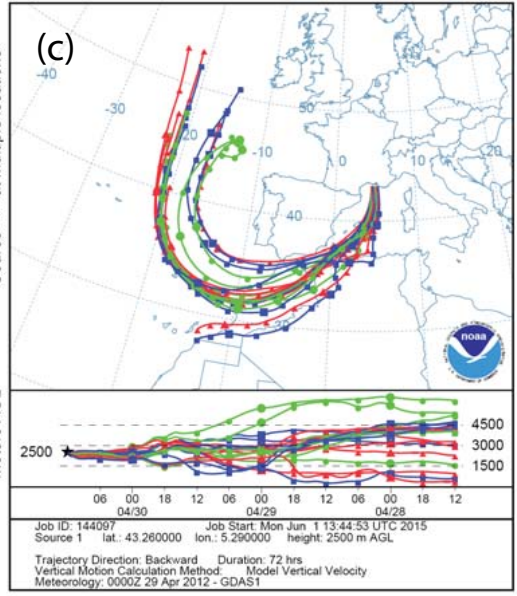

NOAA HYSPLIT MODEL

Backward trajectories ending at 1200 UTC 01 Jul 12 GDAS Meteorological Data

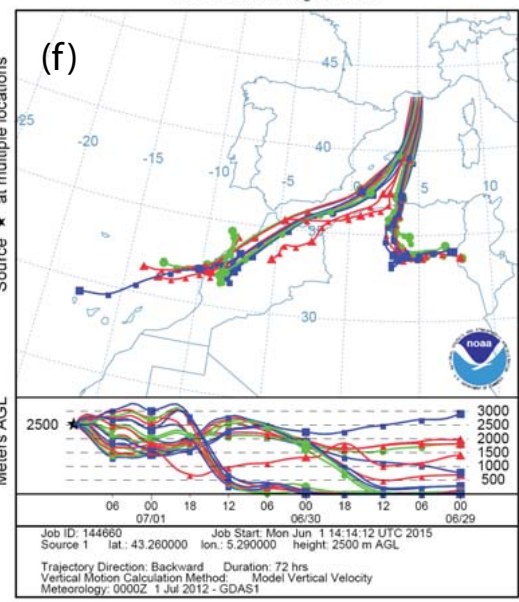

NOAA HYSPLIT MODEL

Backward trajectories ending at 1200 UTC 29 Sep 12 GDAS Meteorological Data

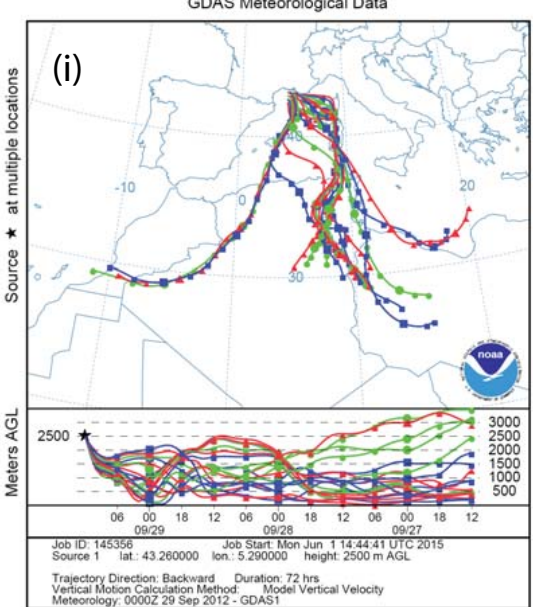

Figure 4. HYSPLIT backward air mass trajectories computed for $72 \mathrm{~h}$ at multiple locations in the surrounding of Frioul site for the nine main deposition events recorded on Frioul Island: (a) 11 July 2011, 12:00 UTC, at 2500 m a.g.1.; (b) 25 October 2011, 00:00 UTC, at 2500 m a.g.1.; (c) 30 April 2012, 12:00 UTC, at 2500 m a.g.1.; (d) 20 May 2012, 18:00 UTC, at $500 \mathrm{~m}$ a.g.1.; (e) 20 June 2012, 12:00 UTC, at 2500 m a.g.1.; (f) 01 July 2012, 12:00 UTC, at 2500 m a.g.1.; (g) 25 August 2012, 12:00 UTC, at 500 m a.g.1.; (h) 05 September 2012, 12:00 UTC, at 2500 a.g.1.; (i) 29 September 2012, 12:00 UTC, at $2500 \mathrm{~m}$ a.g.1. 
Martin (1996) in Corsica. Ternon et al. (2010) showed maximum deposition in February 2004 due to a huge dust event and in late spring (June). These seasonal differences can be explained by the large dust deposition variability caused by intense sporadic events observed in the northern Mediterranean Basin (Loÿe-Pilot and Martin, 1996; Ternon et al., 2010).

For the major deposition events measured at the Frioul site, AOD from MODIS AQUA and TERRA observations ranged from 0.3 to 0.7 , suggesting significant atmospheric loads in particulate matter. The origins of the air masses reaching the Frioul site for the nine main deposition events measured were analyzed using the HYSPLIT model backward trajectories (https://ready.arl.noaa.gov/HYSPLIT.php) (Fig. 4). The HYSPLIT trajectories computed for the major mineral deposition events (a, b, c, d, e, f, g and i) indicate air masses originating from the southern Mediterranean Basin and North Africa. For one event (h) the air mass trajectories suggest a stagnant meteorological situation over the Gulf of Lions and the Western Mediterranean Basin.

\section{Conclusions}

An automatic collector (CARAGA) has been specially developed to sample total (dry and wet) insoluble atmospheric deposition, and a protocol for the treatment of the collected samples implying ignition and weighing has been tested. This protocol enabled us to focus on the mineral fraction of the deposition, most of the organic particles being volatilized or oxidized at $550^{\circ} \mathrm{C}$.

The present study on the estimates of Saharan dust deposition on Frioul Island, a site located in the Gulf of Lions, illustrates the use of a CARAGA. The collector has worked continuously for almost 2 years and provided weekly total deposition samples. Insoluble mineral deposition measured on Frioul Island is $2.45 \mathrm{~g} \mathrm{~m}^{-2}$ for February to December 2011 and $3.16 \mathrm{~g} \mathrm{~m}^{-2}$ for January to October 2012, which corresponds to low deposition amounts without very strong dust deposition events in the north-western Mediterranean Basin. The weekly deposits of insoluble mineral particles range over 2 orders of magnitude. Nine major events with mineral deposition ranging from $1.5 \times 10^{-1}$ to $3.3 \times 10^{-1} \mathrm{~g} \mathrm{~m}^{-2}$ were recorded on Frioul Island. During this period, the major deposition events occurred more frequently during spring and summer. Precipitations, ranging from 1.0 to $80.8 \mathrm{~mm}$, are associated to seven of these dust event periods, precipitation data having not totally or partly being recorded for the two other dust event periods. Nine main mineral deposition events are measured in periods during which MODIS aerosol optical depth is high. Air masses passing over the Frioul site during these periods came from the southern Mediterranean Basin and North Africa. These elements strongly indicate that the higher deposition events measured on Frioul Island are due to Saharan dust transport associated to local precipitation.
In order to improve Saharan dust deposition monitoring in the Mediterranean Basin and the south of France, CARAGA collectors are now deployed over eight stations located in France, Spain, Italy and Tunisia: Frioul $\left(43.27^{\circ} \mathrm{N} ; 5.29^{\circ} \mathrm{E}\right)$, Le Casset $\left(44.99^{\circ} \mathrm{N} ; 6.47^{\circ} \mathrm{E}\right)$, Montandon $\left(47.28^{\circ} \mathrm{N} ; 6.82^{\circ} \mathrm{E}\right)$, Cap Corse $\left(43.00^{\circ} \mathrm{N} ; 9.36^{\circ} \mathrm{E}\right)$, Mallorca $\left(39.27^{\circ} \mathrm{N} ; 3.05^{\circ} \mathrm{E}\right)$, Sierra Nevada $\left(36.95^{\circ} \mathrm{N}\right.$; $\left.3.43^{\circ} \mathrm{W}\right)$, Lampedusa $\left(35.52^{\circ} \mathrm{N} ; 12.63^{\circ} \mathrm{E}\right)$ and Medenine $\left(33.50^{\circ} \mathrm{N} ; 10.64^{\circ} \mathrm{E}\right)$. These constitute an operating and standardized network of total insoluble dust deposition. As such, it should provide us with a promising basis to document the multiannual spatial and temporal variability of mineral dust deposition and to constrain CTM dust simulation over the Western Mediterranean region.

\section{The Supplement related to this article is available online at doi:10.5194/amt-8-2801-2015-supplement.}

Acknowledgements. This study was funded by the PRIMEQUALADEME program on "Pollution atmosphérique longue distance" through the research project "Mesure du dépôt atmosphérique et validation de sa représentation dans les modèles régionaux" (DEMO project, contract no. 0962c0067). This project was supported by the Chemistry Aerosol Mediterranean Experiment (ChArMEx project; http://charmex.lsce.ipsl.fr/) funded by CNRS/INSU, ADEME, Météo-France and CEA in the framework of the program MISTRALS (http://www.mistrals-home.org). The development of the CARAGA collector was supported both by the Chemistry Faculty of Paris Diderot University and the PRIMEQUAL-ADEME DEMO project. The authors would like to thank M.-D. Loÿe-Pilot, F. Peters and an anonymous reviewer for their insightful and helpful comments on the manuscript. We thank François Dulac for the research at a field site and support of the project since initial discussions. We also thank the HYSPLIT teams for making the backward air mass trajectories available.

Edited by: N. Mihalopoulos

\section{References}

Avila, A., Alarcon, M., Castillo, S., Escudero, M., Garcıa Orellana, J., Masque, P., and Querol X.: Variation of soluble and insoluble calcium in red rains related to dust sources and transport patterns from North Africa to northeastern Spain, J. Geophys. Res., 112, D05210, doi:10.1029/2006JD007153, 2007.

Ball, D. F.: Loss-on-ignition as an estimate of organic soils matter and carbon in-non calcareous soils, J. Soil Sci., 15, 84-92, 1964.

Barlow, A. K. and Latham, J.: A laboratory study of the scavenging of sub-micronaerosol by charged raindrops, Q. J. R. Meteor. Soc., 109, 763-770, 1983.

Bergametti, G.: Apports de matière par voie atmosphérique à la Méditerranée Occidentale: aspects géochimiques et météorologiques, Thèse d'état, Univ. Paris VII, France, 296 pp, 1987. 
Bergametti, G. and Forêt, G.: Dust deposition, in Mineral Dust: a Key Player in the Earth System, edited by: Knippertz, P. and Stuut, J.-B. W., Springer, Dordrecht, the Netherlands, 179-200, 2014.

Bergametti, G., Dutot, A. L., Buat-Ménard, P., Losno, R., and Remoudaki, E.: Seasonal variability of the elemental composition of atmospheric aerosol particles over the northwestern Mediterranean, Tellus, 41B, 353-361, 1989.

Bonnet, S. and Guieu, C.: Atmospheric forcing on the annual iron cycle in the western Mediterranean Sea: A 1-year survey, J. Geophys. Res., 111, C09010, doi:10.1029/2005JC003213, 2006.

Chamberlain, A. C.: Transport of lycopodium spores and other small particles to rough surfaces, P. Roy. Soc. Lond. A Mat., A296, 45-70, 1967.

Claassen, H. C. and Halm, D. R.: Performance characteristics of an automated wet deposition collector and possible effect on computed annual deposition, Atmos. Environ., 29, 1021-1026, 1995.

Dana, M. T. and Hales, J. M.: Statistical aspects of the washout of polydisperse aerosols, Atmos. Environ., 10, 45-50, 1976.

Desboeufs, K., Losno, R., Vimeux, F., and Cholbi S.: The pH dependent dissolution of wind transported Saharan dust, J. Geophys. Res., 104, 21287-21299, 1999.

Etyemezian, V., Gillies, J., Kuhns, H., Nikolic, D., Watson, J., Veranth, J., Laban, R., Seshadri, G., and Gillette, D.: Field Testing and Evaluation of Dust Deposition and Removal Mechanisms: Final Report, Desert Research Institute, Las Vegas, NV, 2003.

Galy-Lacaux, C., Laouali, D., Descroix, L., Gobron, N., and Liousse, C.: Long term precipitation chemistry and wet deposition in a remote dry savanna site in Africa (Niger), Atmos. Chem. Phys., 9, 1579-1595, doi:10.5194/acp-9-1579-2009, 2009.

Garcia Nieto, P. J., Arganza Garcia, B., Fernandez Diaz, J. M., and Rodriguez Brana, M. A.: Parametric study of selective removal of atmospheric aerosol by below-cloud scavenging, Atmos. Environ., 28, 2235-2342, 1994.

Goossens, D.: Quantification of the dry aeolian deposition of dust on horizontal surfaces: an experimental comparison of theory and measurements, Sedimentology, 52, 859-873, 2005.

Goossens, D.: Relationships between horizontal transport flux and vertical deposition flux during dry deposition of atmospheric dust particles, J. Geophys. Res., 113, F02S13, doi:10.1029/2007JF000775, 2008.

Goossens, D. and Rajot, J. L.: Techniques to measure the dry aeolian deposition of dust in arid and semi-arid landscapes: a comparative study in West Niger, Earth Surf. Proc. Land., 33, 178195, doi:10.1002/esp.1533, 2008.

Guerzoni, S., Landuzzi, W., Lenaz, R., Quarantotto, G., Rampazzo, G., Molinaroli, E., Turetta, C., Visin, F., Cesari, G., and Cristini, S.: Fluxes of soluble and insoluble metals and nutrients from the atmosphere to the central Mediterranean Sea, Water Poll. Res. Rep., 30, 438-493, 1993.

Guieu, C., Loÿe-Pilot, M. D., Benyaya, L., and Dufour, A.: Spatial variability of atmospheric fluxes of metals (Al, Fe, Cd, $\mathrm{Zn}$ and $\mathrm{Pb})$ and phosphorus over the whole Mediterranean from a oneyear monitoring experiment: Biogeochemical implications, Mar. Chem., 120, 165-179, 2010.

Heimburger, A., Losno, R., Triquet, S., and Bon Nguyen, E.: Atmospheric deposition fluxes of 26 elements over the Southern Indian Ocean: time series on Kerguelen and Crozet Islands, Global Biogeochem. Cy., 27, 440-449, 2013.
Herrmann, L.: Staubdeposition auf Böden West Afrikas, Eigenschaften und Herkunftsgebiete der Stäube und ihr Einfluss auf Böden und Standortseigenschaften, PhD Thesis, Hohenheim Bodenkundliche Hefte 36, University of Hohenheim, Stuttgart, Germany, 1996.

Hoenig, M. and Thomas, P.: Préparation d'échantillons de l'environnement pour analyse minérale, Techniques de l'ingénieur Analyses dans l'environnement, vol. TIB382DUO, ref. p4150, Edition T. I., Paris, France, 12 pp., 2002.

Jung, E. and Shao, Y.: An intercomparison of four wet deposition schemes used in dust transport modeling, Global Planet. Change, 52, 248-260, 2006.

Kouvarakis, G., Mihalopoulos, N., Tselepides, A., and Stavrakakis, S.: On the importance of atmospheric inputs of inorganic nitrogen species on the productivity of the eastern Mediterranean Sea; Global Biogeochem. Cy., 15, 805-817, 2001.

Lafon, S., Alfaro, S. C., Chevaillier, S., and Rajot, J. L.: A new generator for mineral dust aerosol production from soil samples in the laboratory: GAMEL, Aeolian Research, 15, 319-334, 2014.

Lambert, G. and Nezami, M.: Importance des retombées sèches dans le bilan du plomb-210, Annal. Geophys., 21, 245-251, 1965.

Lelieveld, J., Berresheim, H., Borrmann, S., Crutzen, P. J., Dentener, F. J., Fischer, H., Feichter, J., Flatau, P. J., Heland, J., Holzinger, R., Korrmann, R., Lawrence, M. G., Levin, Z., Markowicz, K. M., Mihalopoulos, N., Minikin, A., Ramanathan, V., de Reus, M., Roelofs, G. J, Scheeren, H. A., Sciare, J., Schlager, H., Schultz, M., Siegmund, P., Steil, B., Stephanou, E. G., Stier, P., Traub, M., Warneke, C.,Williams, J., and Ziereis, H.: Global Air Pollution Crossroads over the Mediterranean, Science, 298, 794-799, 2002.

Leong, K. H., Beard, K. V., and Ochs III, H. T.: Laboratory measurements of particle capture by evaporating cloud drops, J. Atmos. Sci., 39, 1130-1140, 1982.

López-García, P., Gelado-Caballero, M. D., Santana-Castellano, D., Suárez de Tangil, M., Collado-Sánchez, C., and HernándezBrito, J. J.: A three-year time-series of dust deposition flux measurements in Gran Canaria, Spain: A comparison of wet and dry surface deposition samplers, Atmos. Environ., 79, 689-694, 2013.

Losno, R.: Chimie d'éléments minéraux en trace dans les pluies Méditerranéennes, $\mathrm{PhD}$ Thesis, Université Paris7, France, 184 pp., 1989.

Loÿe-Pilot, M. D. and Martin, J. M.: Saharan dust input to the Western Mediterranean: an eleven years record in Corsica, in: The impact of desert dust across the Mediterranean, edited by: Guerzoni, S. and Chester, R., Kluwer Acad. Publ., Dordrecht, the Netherlands, 191-199, 1996.

Markaki, Z., Loÿe-Pilot, M. D., Violaki, K., Benyahya, L., and Mihalopoulos, N.: Variability of atmospheric deposition of dissolved nitrogen and phosphorus in the Mediterranean and possible link to the anomalous seawater N/P ratio, Mar. Chem., 120, 187-194, 2010.

Morales-Baquero, R., Pulido-Villena, E., and Reche, I.: Chemical signature of Saharan dust on dry and wet atmospheric deposition in the south-western Mediterranean region, Tellus B, 65, 18720, doi:10.3402/tellusb.v65i0.18720, 2013.

Orange, D., Gac, J. Y., Probst, J. L., and Tanre, D.: Mesure du dépôt au sol des aérosols désertiques. Une méthode simple de prélève- 
ment: le capteur pyramidal, Comptes rendus de l'Académie des Sciences Paris, 311, 167-172, 1990.

Osada, K., Ura, S., Kagawa, M., Mikami, M., Tanaka, T. Y., Matoba, S., Aoki, K., Shinoda, M., Kurosaki, Y., Hayashi, M., Shimizu, A., and Uematsu, M.: Wet and dry deposition of mineral dust particles in Japan: factors related to temporal variation and spatial distribution, Atmos. Chem. Phys., 14, 1107-1121, doi:10.5194/acp-14-1107-2014, 2014.

Ozsoy, T.: Atmospheric wet deposition of soluble macro-nutrients in the Cilician Basin, north-eastern Mediterranean sea, J. Environ. Monit., 5, 971-976, 2003.

Pey, J., Querol, X., Alastuey, A., Forastiere, F., and Stafoggia, M.: African dust outbreaks over the Mediterranean Basin during 2001-2011: $\mathrm{PM}_{10}$ concentrations, phenomenology and trends, and its relation with synoptic and mesoscale meteorology, Atmos. Chem. Phys., 13, 1395-1410, doi:10.5194/acp-13-13952013, 2013.

Pranesha, T. S. and Kamra, A. K.: Scavenging of aerosol particles by large water drops: 1. Neutral case, J. Geophys. Res., 101, 23373-23380, doi:10.1029/96JD01311, 1996.

Prospero, J. M., Landing, W. M., and Schulz, M.: African dust deposition to Florida: Temporal and spatial variability and comparisons to models, J. Geophys. Res., 115, D13304, doi:10.1029/2009JD012773, 2010.

Pulido-Villena, E., Wagener, T., and Guieu, C.: Bacterial response to dust pulses in the western Mediterranean: Implications for carbon cycling in the oligotrophic ocean, Global Biogeochem. Cy., 22, GB1020, doi:10.1029/2007GB003091, 2008.

Rajot, J. L.: Wind-blown sediment mass budget of Sahelian village land units in Niger, Bulletin de la Société Géologique de France, 172, 523-531, 2001.

Remoudaki, E., Bergametti, G., and Buat-Ménard, P.: Temporal variability of atmospheric lead concentrations and fluxes over the Northwestern Mediterranean Sea, J. Geophys. Res., 96, 1043$1055,1991$.

Ridame, C., Guieu, C., and Loÿe-Pilot, M. D.: Trend in total atmospheric deposition fluxes of aluminium, iron, and trace metals in the northwestern Mediterranean over the past decade (1985-1997), J. Geophys. Res., 104, 30127-30138, doi:10.1029/1999JD900747, 1999.

Rognon, P., Coudé-Gaussen, G., Revel, M., Grousset, F. E., and Pedemay, P.: Holocene saharan dust deposition on the Cape Verde Islands: Sedimentological and $\mathrm{Nd}-\mathrm{Sr}$ isotopic evidence, Sedimentology, 43, 359-366, 1996.

Sciare, J., Oikonomou, K., Cachier, H., Mihalopoulos, N., Andreae, M. O., Maenhaut, W., and Sarda-Estève, R.: Aerosol mass closure and reconstruction of the light scattering coefficient over the Eastern Mediterranean Sea during the MINOS campaign, Atmos. Chem. Phys., 5, 2253-2265, doi:10.5194/acp-5-2253-2005, 2005.

Seinfeld, J. H. and Pandis, S. N.: Atmospheric Chemistry and Physics: From Air Pollution to Climate Change, J. Wiley, New York, USA, 136 pp., 1998.

Sheldon, R. W.: Size separation of marine seston by membrane and glass-fiber filters, Limnol. Oceanogr., 17, 494-498, 1972.

Slinn, S. A. and Slinn, W. G. N.: Predictions for particle deposition on natural waters, Atmos. Environ., 14, 1013-1016, 1980.
Slinn, W. G. N.: Precipitation scavenging, In Atmospheric Sciences and Power Production, chapter 11, edited by: Randerson, D., 466-532, no. DOE/TIC-27601 (DE84005177), Office of Health and Environmental Research, Division of Biomedical Environmental Research, U.S. Dept. of Energy, Washington, DC, 1984.

Sow, M., Goossens, D., and Rajot, J. L.: Calibration of the MDCO dust collector and of four versions of the inverted frisbee dust deposition sampler, Geomorphology, 82, 360-375, 2006.

Sun, H., Nelson, M., Chen, F., and Husch, J.: Soil mineral structural water loss during loss on ignition analyses, Can. J. Soil Sci., 89, 603-610, 2009.

Ternon, E., Guieu, C., Loÿe-Pilot, M.-D., Leblond, N., Bosc, E., Gasser, B., Miquel, J.-C., and Martín, J.: The impact of Saharan dust on the particulate export in the water column of the North Western Mediterranean Sea, Biogeosciences, 7, 809-826, doi:10.5194/bg-7-809-2010, 2010.

Textor, C., Schulz, M., Guibert, S., Kinne, S., Balkanski, Y., Bauer, S., Berntsen, T., Berglen, T., Boucher, O., Chin, M., Dentener, F., Diehl, T., Easter, R., Feichter, H., Fillmore, D., Ghan, S., Ginoux, P., Gong, S., Grini, A., Hendricks, J., Horowitz, L., Huang, P., Isaksen, I., Iversen, I., Kloster, S., Koch, D., Kirkevåg, A., Kristjansson, J. E., Krol, M., Lauer, A., Lamarque, J. F., Liu, X., Montanaro, V., Myhre, G., Penner, J., Pitari, G., Reddy, S., Seland, $\emptyset .$, Stier, P., Takemura, T., and Tie, X.: Analysis and quantification of the diversities of aerosol life cycles within AeroCom, Atmos. Chem. Phys., 6, 1777-1813, doi:10.5194/acp-6-1777-2006, 2006.

Theodosi, C., Markaki, Z., and Mihalopoulos, N.: Iron speciation, solubility and temporal variability in wet and dry deposition in the Eastern Mediterranean, Mar. Chem., 120, 100-107, 2010.

Venkatram, A. and Pleim, J.: The electrical analogy does not apply to modeling dry deposition of particles, Atmos. Environ., 33, 3075-3076, 1999.

Wang, P. K. and Pruppacher, H. R.: An experimental determination of the efficiency with which aerosol particles are collected by water drops in subsaturated air, J. Atmos. Sci., 34, 1664-1669, 1977.

Wesely, M. L.: Parameterizations of surface resistance to gaseous dry deposition in regional-scale numerical models, Atmos. Environ., 23, 1293-1304, 1989.

Whitby, K. T. and Cantrell, B. K.: Atmospheric Aerosols: Characteristics and Measurement, International Conference on Environmental Sensing and Assessment (ICESA), Institute of Electrical and Electronic Engineers (IEEE), 14-19 September 1975, Las Vegas, NV, USA, 1976.

Wiggs, G. F. S., Leys, J., McTainsh, G. H., Heidenrich, S., and Strong, C.: A wind tunnel study of the collection efficiency of an aerodynamically improved "Frisbee" dust trap, Proc. ICAR5/GCTE-SEN Joint Conference, Int. Center for Arid and Semiarid Land Studies, Texas Tech University, Lubbock, Texas, USA, Publ. 02-2, 133-141, 2-25 July 2002.

Zhao, T. L., Gong, S. L., Zhang, X. Y., and McKendry, I. G.: Modeled size-segregated wet and dry deposition budgets of soil dust aerosol during ACE - Asia 2001: Implications for trans-Pacific transport, J. Geophys. Res., 108, 8665, doi:10.1029/2002JD003363, 2003. 